\title{
Photovoltaic solar power for a wastewater electrocoagulation prototype
}

\section{Alimentación solar fotovoltaica para un prototipo de electrocoagulación de aguas residuales}

\author{
CANTERA-CANTERA, Luis Alberto†* \& CALVILLO-TÉLLEZ, Andrés \\ Instituto Politécnico Nacional, School of Mechanical and Electrical Engineering, Mexico.
}

ID $1^{\text {st }}$ Author: Luis Alberto, Cantera-Cantera / ORC ID: 0000-0003-2828-6779

ID $1^{\text {st }}$ Coauthor: Andrés, Calvillo-Téllez / ORC ID: 0000-0003-3721-5630

DOI: $10.35429 /$ JSTA.2020.18.6.32.36

Received: July 25, 2020; Accepted: December 30, 2020

\begin{abstract}
A photovoltaic solar power supply is presented; it supplies energy to the electrodes of a wastewater treatment prototype by electrocoagulation. The source will be able to supply three voltages levels 10,20 , and 30 volts, with a current of $1000 \mathrm{~mA}$. The system consists of an array of solar panels and Nickel Metal batteries. The amount of energy to be supplied by the solar panels is estimated, the level of storage in batteries is calculated and fed to the electrocoagulation system. The results of an experiment that operates independently of the power supply line and that works in rural areas are presented.
\end{abstract}

Wastewater, Electrocoagulation, Photovoltaic solar energy

\begin{abstract}
Resumen
Se presenta una fuente de alimentación solar fotovoltaica que suministra energía a los electrodos de un prototipo de tratamiento de aguas residuales por electrocoagulación. La fuente podrá suministrar tres niveles de tensión 10, 20 y 30 volts, con una corriente de $1000 \mathrm{~mA}$. El sistema está constituido por un arreglo de paneles solares y una pila de baterías de Níquel Metal. Se estima la cantidad de energía que deben suministrar los paneles solares se calcula el nivel de almacenamiento en baterías y se alimenta al sistema de electrocoagulación. Se presentan los resultados de un experimento que funciona de forma independiente de la línea de suministro energético y que es funcional en áreas rurales.
\end{abstract}

Aguas residuales, Electrocoagulación, Energía solar fotovoltaica

Citation: CANTERA-CANTERA, Luis Alberto \& CALVILLO-TÉLLEZ, Andrés. Photovoltaic solar power for a wastewater electrocoagulation prototype. Journal of Scientific and Technical Applications. 2020. 6-18:32-36.

\footnotetext{
* Correspondence to Author (Email: lcanterac@ipn.mx)

$\dagger$ Researcher contributing as first author.
} 


\section{Introduction}

Water is vital for the kingdoms, plant, animal and human, it is crucial in the link between society and the environment. The scarce and the bad use deteriorates the development and its environment. The main source of contamination of water bodies is constituted by residual discharges, especially of the domestic or industrial type. $70 \%$ of water bodies show some indication of contamination. On the other hand, electrocoagulation becomes a viable alternative to reduce the impact on the mantles and as a way to recover bodies of water.

Electrocoagulation (EC) is a technique that is applied in the removal of contaminants from water such as: metals, organic contaminants, dyes, pigments, colloidal solids, soluble inorganic contaminants, among others. It has been proposed in recent years as an effective method of treating wastewater. EC involves the anodic dissolution of a metal, typically aluminum or iron, by supplying an electrical current. Followed by the phenomenon of hydrolysis producing flocs, which destabilize, add suspended particles and absorb dissolved pollutants.

The electric current provides the energy that triggers a series of chemical reactions, the end result of which is the stability of the polluting molecules. When it stabilizes, it generates less colloidal and less emulsified or soluble solid particles. When this occurs, the contaminants form floating material, facilitating its removal through the floating sludge evacuation duct. On the other hand, the bottom sludge comes from the metal ions that are released and dispersed in the liquid medium and tend to form metal oxides that electrically attract contaminants that have been destabilized and are removed by the sludge evacuation duct. The remaining liquid is removed through the effluent pipeline [Arango 2012].

Since there are rural areas where there is no infrastructure to supply electricity to power the treatment process [Hernández, 2020]. Photovoltaic solar energy is viable to power small EC plants and put this process into operation, which can have successful results in its application, optimizing the factors that make it up, reaching the challenge of protecting, conserving and recovering the water resource.

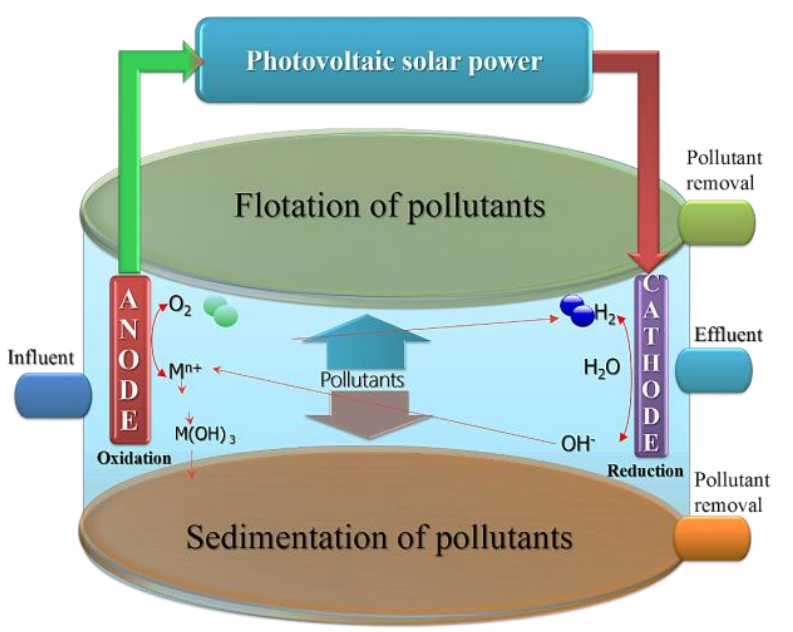

Figure 1 Electrocoagulation system Source: Own elaboration

\section{Method}

The photovoltaic power system must supply a load that demands 10, 20 and 30 Volts at 1000 $\mathrm{mA}$, in periods of time of $30,60,90$ and 120 minutes. The power source must provide the necessary and sufficient energy required by the loads, both with incidence of light and in the absence [Delgado, 2020]. For this, the current demand of the loads is calculated and the solar panels are sized [Sesma, 2020].

The power subsystem is basically constituted by the elements presented in Figure 2, these are:

A primary source of energy, such as direct solar radiation.

- A device for converting primary energy into electrical energy.

A device for storing electrical energy to meet the demands in case of overloads or hours without light.

A system for conditioning, charging, discharging, regulating and distributing the electrical energy generated at voltage levels specified by the corresponding loads.

The solar radiation incident in the vicinity of our planet is $135.3 \mathrm{~mW} / \mathrm{cm} 2$ [Larson and Wertz, 1992].

The use of solar radiation through photovoltaic conversion requires the use of batteries that use electrochemical processes whose typical efficiency is $75 \%$. 
Figure 2 shows the power system, it has among other functions to regulate the battery charge drained by the solar panels. Using a current sensor it detects the amount of energy drained to the batteries and with another it determines how much energy it supplied to the electrodes. It also monitors the voltage of each solar panel, and the temperature of the batteries [Portilla, 2015].

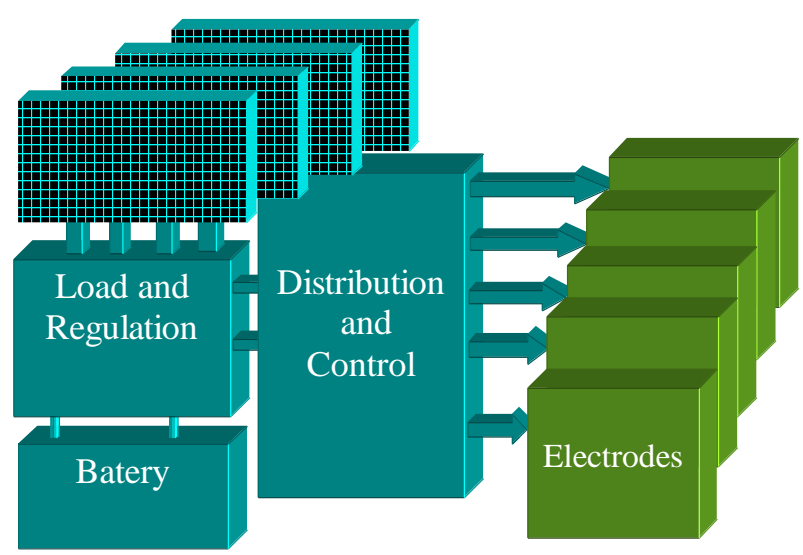

Figure 2 Photovoltaic solar power system and electrocoagulation cells

Source: Own elaboration

Battery charging is done in two ways, one is by measuring temperature; When an increase in temperature is detected with respect to that of its environment, charging stops, as this is an indication that the batteries have reached their maximum charge. The second way is by voltage level, if it is the case, each cell has an increase of $50 \mathrm{mV}$, at this moment the level detector blocks the charge of the solar panel, it is also responsible for prolonging the life of the battery by controlling the reason loading-unloading [Lindao, 2020].

\section{Solar cells and arrays}

The first silicon solar cells were developed at Bell Laboratories in 1953 [Rauschenbach, 1980] and used for the first time in space application in 1958 on the VANGUARD-1 spacecraft to generate electrical power. Conversion efficiency with silicon cells has improved from $4 \%$ initially, up to $20 \%$ today. Generally, a solar module is affected by the environment in the same way as an individual cell. The voltage of a solar cell decreases when the temperature increases and the current increases when the intensity of the radiation increases.
Using BSFR silicon solar cells, textured $25.0 \mathrm{~mm} \times 62.0 \mathrm{~mm}$ area in two parallel series of 44 cells each and mounted on a $434 \mathrm{~mm} \times 419$ $\mathrm{mm}$ panel, and isolated from the structure with a 50 micron kapton sheet of thickness. Cell efficiency is $14 \%$ at the beginning of life. The solar energy intercepted by the solar panel is $185.23 \mathrm{~W}$, considering cell efficiency of $14 \%$, with normal incidence, plus losses due to the blocking diode and the wiring there is at the output of the solar panel at the beginning of life, $25.2 \mathrm{~W}$ at a maximum power voltage of $21 \mathrm{~V}$ and a maximum current of $1.2 \mathrm{~A}$. Assuming normal solar incidence or on two faces with panels at $45 \mathrm{o}$, the power of $25.2 \mathrm{~W}$ of the solar cells is conserved. This power is what can be distributed among the cells [Urquijo, 2020].

\section{Battery}

A sudden current demand in excess of $10 \%$ of the maximum conversion capacity of the solar cells can severely damage the cells. Therefore, in photovoltaic systems, which have variable loads, it is necessary to use rechargeable batteries. Batteries also serve as a power source in shady periods and can be recharged in sunny periods. Batteries must be capable of receiving and supplying power at different levels and at different times, in a large number of charge and discharge cycles. A high recharge efficiency is required, with a hermetic seal that prevents electrolyte loss and corrosion due to pressure and temperature changes. Although there are a variety of batteries, $\mathrm{NiCd}$ batteries were selected because they have shown good performance [Sanyo, 2008]

Batteries have good characteristics, among which is a high discharge rate, minimal internal resistance, which in turn enables highspeed discharge and guarantees a stable discharge voltage. Higher reliability with a wide operating temperature range. The rechargeable battery Sanyo HR-D of Nickel-Metal was used whose specifications have $1.2 \mathrm{~V}$ total capacity 7300 mAh [Sanyo, 2008]. 


\section{Energy budget}

Assuming 12 hours of sunlight (12 hours x 60 minutes $=720$ minutes $)$, the solar constant in the vicinity of the earth has a value of $1358 \mathrm{~W} / \mathrm{m} 2$.

$\mathrm{E}_{\text {available }}=\mathrm{P}_{\text {total }} \mathrm{T}_{\text {sol }} \mathrm{E}_{\text {available }}$

$\mathrm{E}_{\text {available }}=25.2 \mathrm{~W}$ x $720 \min \mathrm{E}_{\text {available }}=18144$ Wmin

Carga $_{\mathrm{e}}=\mathrm{I}_{\text {consumption }} \mathrm{V}_{\text {charge }} \mathrm{T}_{\text {operation }}$

The load draws $1000 \mathrm{~mA}, 10 \mathrm{~V}$, for a period of $90 \mathrm{~min}=900 \mathrm{Wmin}$. is defined as:

$\mathrm{E}_{\text {available }}=\mathrm{I}_{\text {bat }} \mathrm{V}_{\text {bat }} \mathrm{N}_{\text {bat }} \mathrm{T}_{\text {cel }}$

$\mathrm{E}=7.3 \mathrm{Ah} * 1.2 \mathrm{~V} * 16$ pilas $* 90 \mathrm{minutos}=210.24 \mathrm{~W}$

$\mathrm{N}_{\text {panel }}=\mathrm{E}_{\text {available }} / \mathrm{E}_{\text {panel }}$

$\mathrm{N}_{\text {panel }}=210.4 \mathrm{~W} / 25.2 \mathrm{~W}=8.34$ panels

This is the energy that the battery will store to meet the demand of the system. The solar module provides $25.2 \mathrm{~W}$ for a period of 12 hours, so with 8 panels of $25.2 \mathrm{~W}$ you have a power of 202.1W. If 50W panels are used, it would be 4 .

\section{Results}

The batteries were subjected to charge-discharge cycles and it was verified that each cell maintained its $1.2 \mathrm{~V}$ voltage and $7300 \mathrm{mAh}$ current characteristics. Illustrated in graphic 1 .

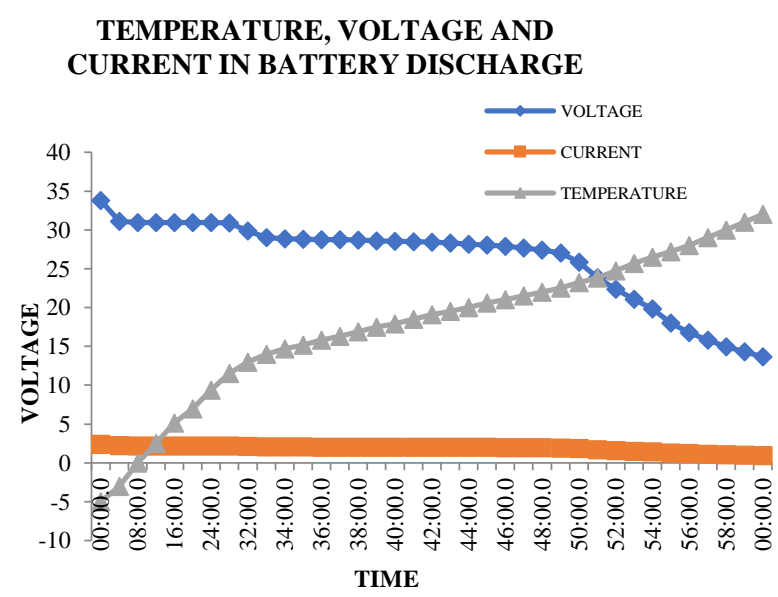

Graphic 1 Charge / discharge tests to battery modules
An electrical voltage of $10 \mathrm{~V}$ of direct current was used in the EC system, a process time of $30,60,90$ and 120 minutes, with 8 aluminum electrodes in a monopolar arrangement, obtaining the measurements shown in graphs 2, 3 and 4.

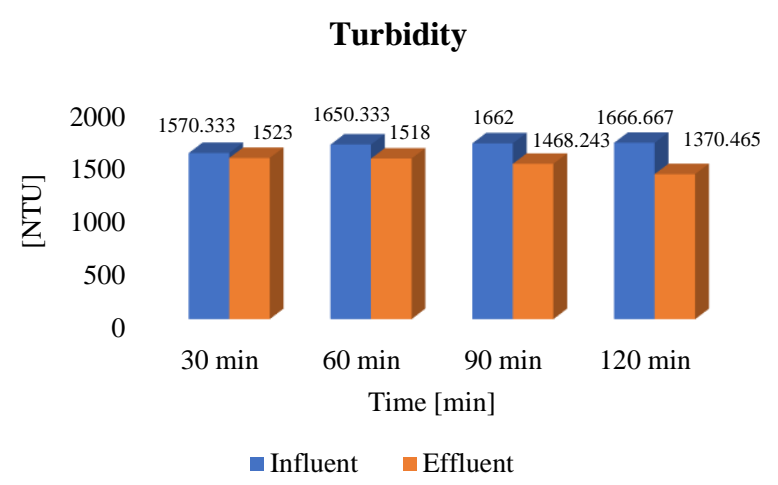

Graphic 2 Comparison of effluent and effluent measurements of Turbidity, applying $10 \mathrm{~V}$

Source: Own elaboration

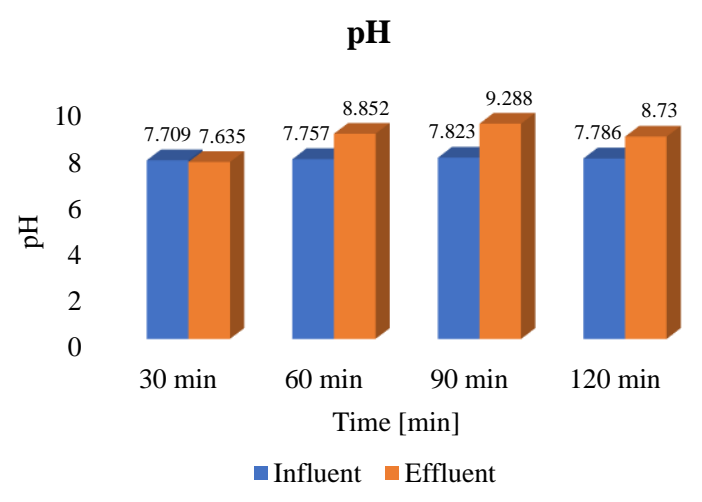

Graphic 3 Comparison of effluent and effluent measurements of the $\mathrm{pH}$ variable, applying $10 \mathrm{~V}$ Source: Own elaboration

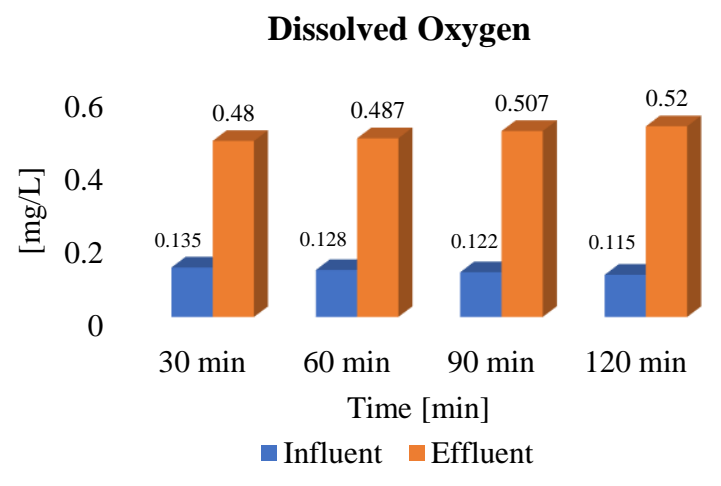

Graphic 4 Comparison of effluent and effluent measurements of the $\mathrm{pH}$ variable, applying $10 \mathrm{~V}$ Source: Own elaboration

Figures 4, 5 and 6 show the behavior of the variable's turbidity, $\mathrm{pH}$ and dissolved oxygen for a constant value of voltage at 10 volts and treatment times of 30,60, 90 and 120 minutes. 
Figure 7 shows a consistent turbidity decrease behavior of the tests, with a greater decrease for the test where 10 volts were applied for a time of 120 minutes.

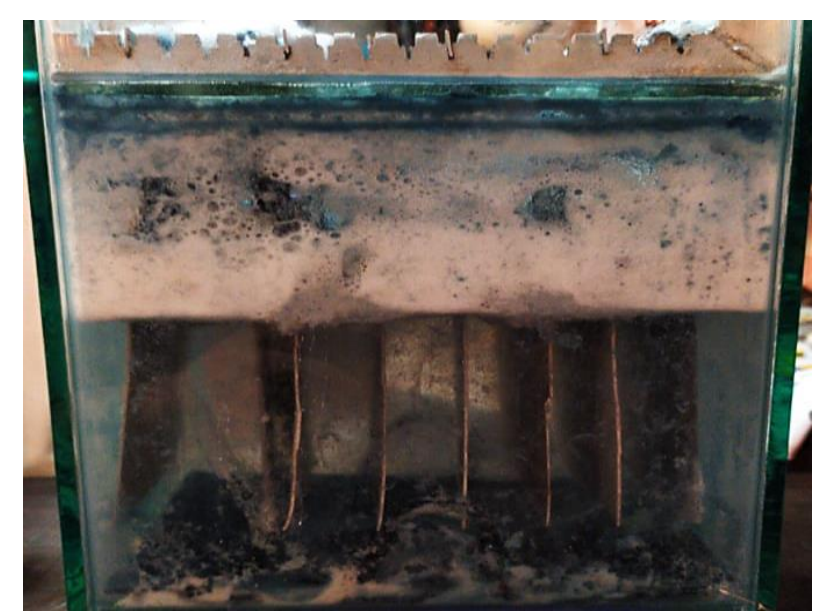

Figure 7 Electrocoagulation process

\section{Acknowledgement}

I thank the National Polytechnic Institute for allowing me to develop the project Voltage and current control system of a solar power module for the electrocoagulation process. SIP Registration 20200191.

\section{Conclusions}

In this work a photovoltaic solar power supply is presented for the application of an electrocoagulation module considering the use of commercial components with extended range characteristics, since it is planned to have a useful life and functionality.

The commitment that exists to provide energy to the electrodes requires making a good budget of energy consumption considering the energy captured by the solar panels and efficiently managing the enabling of the loads, when it is detected that the batteries are full. Efficient current and voltage control to charge the batteries will allow them to last longer.

Using rechargeable batteries with the fast charging feature allows you to take advantage of the ability of these batteries to convert excess charge and recycle it when charged at a rate between 0.5 and $1.5 \mathrm{C}$. This range is supported by the light and shadow cycle of the solar panel. There are other materials that make solar panels more efficient, but their cost is much higher and the improvement in energy collection does not represent a significant improvement.

\section{References}

Chetty, P. (1988). Satellite Technology and Its Applications. PA: Tab Books Inc.

Delgado, A. J. S., Villalón, O. R., \& Sánchez, M. M. L. (2020). Análisis tecno-económico de la operación en esquema de red inteligente y reserva energética en usuarios conectados a paneles fotovoltaicos. Red Internacional de Investigadores en Competitividad, 13, 736-756.

Hernández García, E. (2020). Estudio de una instalación solar fotovoltaica para una vivienda unifamiliar aislada (Doctoral dissertation).

Larson, W. and Wertz J., (1992). Space Mission Analysis and Design. California: Space Technology Series

Lindao Suárez, W. E. (2020). Propuesta de diseño de un sistema de energía solar fotovoltaica. Caso de aplicación en casa comunal de Cooperativa Los Paracaidistas en la ciudad de Guayaquil.

Portilla Álvarez, J. A. (2015). Diseño y Construcción de un Sistema de Control de Carga y Demanda para Sistemas Fotovoltaicos (Doctoral dissertation, Universidad Internacional SEK).

Rauschenbach, H., (1980). Solar Cell Array Design Handbook. New York:VNR.

Sanyo (2008). Data Sheet Nickel-Metal Hydride Rechargeable Batteries. Recuperado de https://www.interempresas.net/FeriaVirtual/Cat alogos_y_documentos/86290/SANYO_nimh.pd f

Sesma Martínez, J. (2020). Monitorización y detección de fallos en una instalación solar fotovoltaica mediante sistema remoto.

Urquijo, K. E. M., \& Junior, O. H. A. (2020). Sensor autônomo para o controle e gerenciamento remoto de um sistema fotovoltaico (Open source-IoT). Revista Brasileira de Iniciação Científica, 7(2), 209220. 